\title{
Żaneta Nejman
}

Higher School of Hotel and Catering Industry in Poznan

e-mail: zan_nej@wp.pl

ORCID: 0000-0002-5732-1476

\section{Joanna Sadłowska-Wrzesińska}

Poznan University of Technology

e-mail: joanna.sadlowska-wrzesinska@put.poznan.pl

ORCID: 0000-0003-1335-6738

THE USE OF INFORMATION

AND COMMUNICATION TECHNOLOGIES

IN THE PROCESS OF INTRODUCING

INCENTIVE SCHEMES

\section{WYKORZYSTANIE TECHNOLOGII \\ INFORMACYJNO-KOMUNIKACYJNYCH \\ W PROCESACH WDRAŻANIA \\ SYSTEMÓW MOTYWACYJNYCH}

DOI: $10.15611 /$ ie.2019.4.04

JEL Classification: M15, M12

Quote as: Nejman, Ż., and Sadłowska-Wrzesińska, J. (2019). The use of information and communication technologies in the process of introducing incentive schemes. Informatyka Ekonomiczna, (4).

Summary: The most important task for a company should be to invest in the development and awareness of its employees, as well as to understand and appreciate them. Motivated employees who bring knowledge and experience to the company contribute to the company's efficiency and success. Therefore, the condition for a sustainable competitive advantage in today's world is the ability to consistently develop the potential of human resources. Progressive globalization, a turbulent environment, and changeability force entrepreneurs to introduce flexible solutions through the use of information and communication technologies in the implementation of incentive systems. Information and communication technologies are an integral part of human life and cover a wide range of information technologies. The main objective of this article is to present the results of research on the effectiveness of individual motivational tools and to assess the impact of dynamically developing information and communication technologies on the formation of motivational systems.

Keywords: ICT Information and Communications Technologies, employee motivation system, Intranet, E-learning, Web 2.0, gamification. 
Streszczenie: Najważniejszym zadaniem dla przedsiębiorstwa powinno być inwestowanie w rozwój i świadomość pracowników, a także ich zrozumienie i docenienie. Zmotywowana kadra wnosząca do firmy wiedzę i doświadczenie przyczynia się do zwiększenia efektywności przedsiębiorstwa i osiagnięcia sukcesu. Zatem warunkiem trwałej przewagi konkurencyjnej we współczesnym świecie staje się zdolność do konsekwentnego rozwijania potencjału zasobów ludzkich. Postępująca globalizacja, turbulentne otoczenie, zmienność wymuszają na przedsiębiorcach wprowadzanie elastycznych rozwiązań poprzez wykorzystanie technologii informacyjno-komunikacyjnych w procesach wdrażania systemów motywacyjnych. Technologie informacyjno-komunikacyjne są nieodłączną częścią życia człowieka i obejmują wiele technologii informacyjnych. Głównym celem niniejszego artykułu jest przedstawienie wyników badań skuteczności poszczególnych narzędzi motywowania oraz próba oceny wpływu dynamicznie rozwijających się technologii informacyjno-komunikacyjnych na kształtowanie się systemów motywacyjnych.

Slowa kluczowe: ICT, system motywowania pracowników, intranet, e-learning, Web 2.0, grywalizacja.

\section{Introduction}

Enterprises operate with the aim of developing their position and making a profit. In order to achieve this, it is necessary to attract committed employees who are the most important capital of the company. Motivated employees who bring knowledge and experience to the company contribute to increasing the effectiveness of the company and achieving success. The condition for a lasting competitive advantage in the modern world is the ability to consistently develop the potential of human resources. Progressive globalization, a turbulent environment, changeability, flexibility, and especially the revolution in information and communication technologies force entrepreneurs to introduce flexible solutions, also in the field of human resources management. Modern solutions in enterprises are used mainly to create incentive systems [Krawczyk-Sokołowska, Mesjasz-Lech, Nowicka-Skowron 2017, pp. 236-246; Chomiak-Orsa, Kołtonowska 2016, pp. 31-34; Marcelle 2000]. According to Chomiak-Orsa, the use of modern information and communication solutions is possible thanks to correlating the computerization strategy with the development strategies of the organization as a whole [Chomiak-Orsa 2013, p. 65].

Activating is a particularly important element of human resources management. Creating effective motivation systems and a targeted HR policy requires identifying the needs of employees and comparing them with the capabilities of the company and the competences of managers. Nowadays, entrepreneurs see the need to construct modern incentive systems with the use of ICT, which is supported by the current situation on the labour market.

The main objective of this article is to present the results of research on the effectiveness of particular motivational tools and to assess the impact of dynamically developing information and communication technologies on the development of 
incentive systems. The study explains the concept of information and communication technologies, presents ideas related to employee motivation, the results of own research and the areas for using information and communication technologies in incentive systems.

\section{Information and communication technologies in the context of the performance of the enterprise's incentive function}

Until recently, the only information carrier was a human being, but with the advent of computers and the Internet the amount of data transmitted has increased very rapidly. Deloitte's research shows that the Internet is actively used by almost half of the world's population, and in Poland by 25.71 million people. The average time that Poles spend on the Internet every day is 4.4 hours and another 1.3 hours browsing websites on mobile devices. In 2016 there were about 14 million active users of social media sites [Raport... 2017]. The term information and communication technologies (ICT) was first used by Denis Stevenson in 1997 and became popular in 2000 in Great Britain [Stevenson 1997, p. 4; Capron 2000, p. 178; Sobińska 2014, p. 126]. The Central Statistical Office defines ICT as follows: "Information and communication technologies (...) are a family of technologies that reproduce, collect and transmit information in an electronic form. A narrower concept is IT, which refers to technologies related to computers and software, but not to communication and network technologies. The development of these technologies makes both concepts more and more coherent, at the same time being the engine of civilisational, social and economic development" [Perspektywy... 2017, p. 15].

Information and communication technologies are an integral part of human life. They include a wide range of information technologies, telecommunication, broadcast media, all kinds of processing, audio and video transmission, and functions of network control and monitoring, analysis and synthesis of information (processing, selection, creation of coherent images from elements located in different areas) [http://proedukator.wordpress.com/2012/01/04/technologieinformacyjnokomunikac yjne-pojecie-ogolne; Sambamurthy 2000; Leoński 2014, pp. 182-184].

It is worth emphasizing here that computer science has a vital role in administration and management; estimating it according to the involved hardware and personnel potential, it is dominating in comparison with other areas of social and economic activity. It was the needs of management that significantly influenced the direction of development of computer hardware and the applied data processing technologies [Klonowski 2004]. The role of IT in organization management cannot be overestimated. More and more research and analysis concern the issues of IT systems classes in management, the optimization of business processes with the use of ERP software and the management of application, technology and project portfolios. There is also the subject of security incident management [Gabryelewicz, Krupa, 
Sadłowska-Wrzesińska 2017], but less often IT issues are addressed in the context of personal functions in an enterprise.

The personnel function is one of the most important functions of enterprise management, and activities related to it are defined as human resources management [Listwan 2010, p. 15]. Motivating is a particularly important element of human resources management. Creating effective motivation systems and a targeted HR policy requires identifying the needs of employees and comparing them with the capabilities of the company and the competences of the managers. Nowadays, entrepreneurs see the need to construct modern incentive systems with the use of ICT, which is supported by the current situation on the labour market (employee market). However, not all owners have the possibilities and means to carry out changes. The implementation of a new incentives system requires changes that cause concern to the company's management; this anxiety is further compounded by the fact that it is impossible to invest specific financial resources in the implementation of the entire project. In a modern economy dominated by information, competitiveness, and innovation, the possibility of survival depends on knowledge, and enterprises operate in a world dominated by modern technologies. According to Kozioł, it is commonly known that the position to be achieved by an enterprise depends on the way in which the most valuable resources of the enterprise - employees - are used [Kozioł, Piechnik-Kurdziel, Kopeć 2000, p. 21]. The most important task for an enterprise should be investing in the development and awareness of employees, as well as their wealth and appreciation [Crozier 1993, pp. 57-58]. Over the years, scientists have not found an answer to the question of how to motivate employees, but it is known that three components of motivation can be distinguished: direction, effort and perseverance [Nieckarz 2011, pp. 19-20]. Figure 1 shows the three components of motivation.
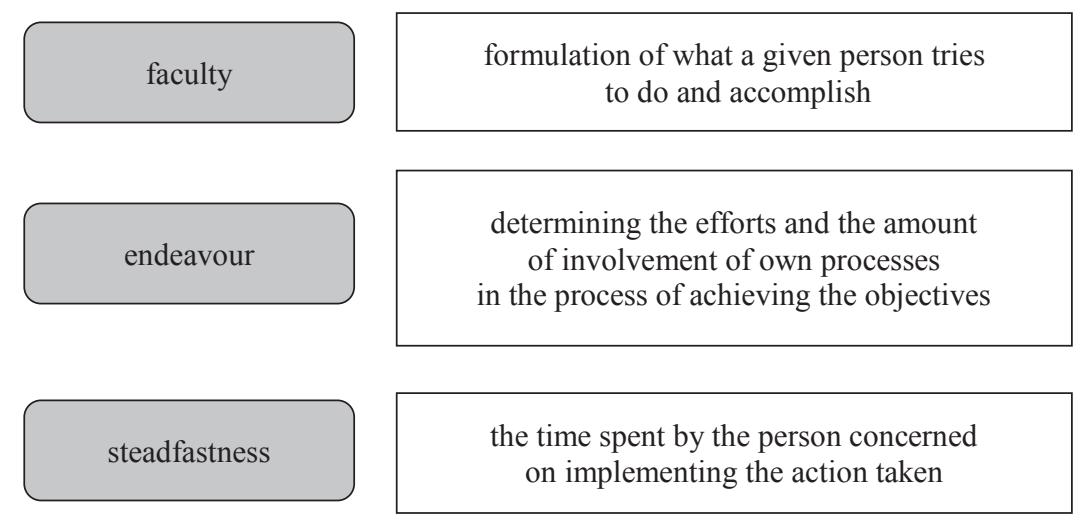

Fig. 1. Components of motivation

Source: [Nieckarz 2011, pp. 19-20]. 
Motivation is the result of a process that begins when the deficit between expectation and the current state of affairs arises [Nieckarz 2011, p. 21]. This concept has many meanings. "Most often it is understood as the state of readiness of a person to take any action" [Nieckarz 2011, p. 21].

The scheme of motivations is shown in Figure 2.

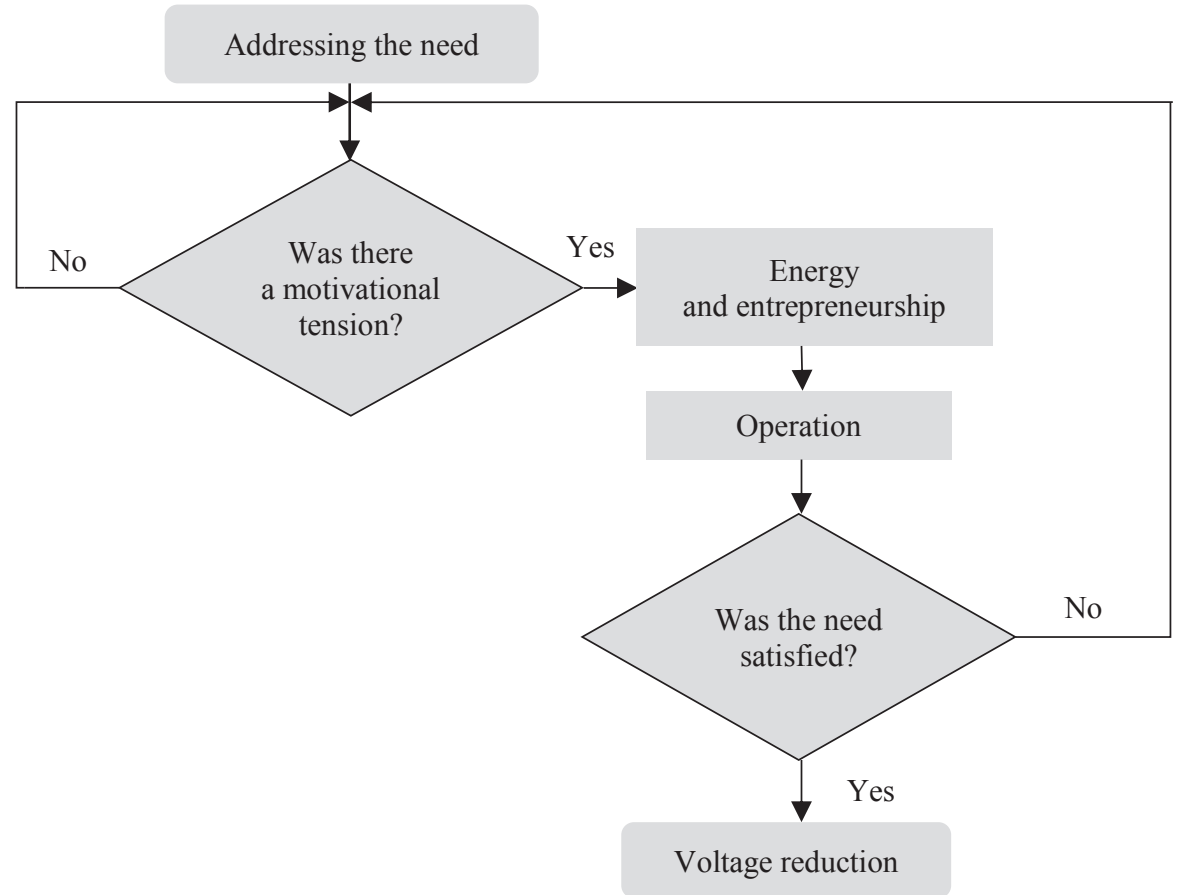

Fig. 2. Motivation scheme

Source: prepared on the basis of [Juchnowicz 2014, p. 390].

In human behaviour one can find motives, i.e. reasons for a given behaviour. The stronger the motivation, the more active the employee is in achieving the desired result. Strong action of the motivation factor may increase the intensity of motivation or worsen the level of work performed. The motivation system concerns most of the processes in the organization. In the practice of enterprises, this comes down mainly to the selection of tools and motivating factors that create the motivation program [Kozioł 2002, p. 8]. It is commonly believed that the motivational system is aimed at the optimal use of employees' potential and the identification of employees with the organisation's objectives. Choosing the right motivating method contributes to the proper use of human resources so that employees can feel an inspiration for their work and initiate the process of innovative thinking [Schermerhorn 2008, pp. 259-260; Sadłowska-Wrzesińska, Nejman 2016, p. 399]. In the motivation 
process, motivation factors are used which can be divided according to different criteria. Table 1 presents a breakdown of motivation factors, taking into account selected criteria.

Table 1. Criteria for the apportionment of incentive factors

\begin{tabular}{|c|c|c|}
\hline \multirow{2}{*}{$\begin{array}{l}\text { Scope of } \\
\text { interactions }\end{array}$} & Internal & Recognition, prestige, independence, development \\
\hline & External & Pay, promotion, sense of security \\
\hline \multirow[t]{2}{*}{ Form } & Payroll & Payroll, bonus awards \\
\hline & Non-salary & $\begin{array}{l}\text { Oral praise, good working conditions, training, } \\
\text { integration trips }\end{array}$ \\
\hline \multirow[t]{2}{*}{ Direction } & Positive & Rewards to strengthen desired behaviour \\
\hline & Negative & $\begin{array}{l}\text { Penalties motivating the avoidance of behaviour } \\
\text { considered undesirable }\end{array}$ \\
\hline \multirow[t]{2}{*}{ Interactions } & Individual & \\
\hline & Team & \\
\hline \multirow[t]{2}{*}{ The way } & Factors satisfying basic stimuli & The life needs of the organism \\
\hline & $\begin{array}{l}\text { Factors satisfying higher-order } \\
\text { stimuli }\end{array}$ & Needs of the social, aesthetic and moral type \\
\hline
\end{tabular}

Source: [Sępek 2010, p. 103].

The increase in the complexity of all processes in organisations and their surroundings necessitates the need to improve management systems. This also applies to the motivating function - a function regulating the behaviour of employees so that their actions contribute to the achievement of the enterprise's objectives. The survival and development of a modern enterprise is becoming more and more challenging for the management and is increasingly dependent on the efficiency of the information system and the ability to use IT tools to efficiently implement individual personnel functions.

\section{Motivating employees in light of own research results}

Empirical research was conducted in the period 2015-2017 in manufacturing companies in the Wielkopolskie voivodeship. A targeted quota selection was applied (non-probabilistic), which allowed to examine such a number of people that the results could be related to the whole population [Steczkowski 1995, pp. 90-91]. Participation in the survey was voluntary and anonymous. The diagnostic survey method was used. The research tool was the own questionnaire, which was checked in the pilot study. The tool consisted of two parts and a certificate. The first part comprised 18 questions about the workplace based on the five-stage Likert scale. The second part included 34 questions related to the motivation factors to work with the point scale from 0 to 4 points. The survey involved 449 employees, 149 women and 300 men. The dominant age group of the respondents were employees aged 
$20-30$, i.e. $39.6 \%$ of the respondents. The age group of $31-40$ years was represented by $27.2 \%$ of people and $22.7 \%$ of people aged $41-50$. The respondents over 50 constituted only $10.5 \%$ of the sample. The main group were those with secondary education - 46.8\%, 26.9\% with higher education and $21.8 \%$ with vocational education, while $4.5 \%$ had primary education; $35.9 \%$ of the respondents declared working in the current company for at least 3 years, while $26 \%$ for a year, $25.8 \%$ of people had worked for no longer than 1 year, and $21.6 \%$ for more than 10 years. The remainder had worked there for 1-3 years and constituted $16.7 \%$ of the respondents. The research indicated that more than half of the respondents $(56.8 \%)$ hold executive positions, and $28.3 \%$ specialist positions in accordance with their qualifications,

Table 2. Averages and standard deviations of intangible factors motivating to work on the scale of 0-4

\begin{tabular}{|c|l|c|c|c|c|}
\hline No. & \multicolumn{1}{|c|}{$\begin{array}{c}\text { Incentive factors for work- } \\
\text { intangible }\end{array}$} & Factor no. & n & Medium & $\begin{array}{c}\text { Standard } \\
\text { deviation }\end{array}$ \\
\hline 1 & \multicolumn{1}{|c|}{2} & 3 & 4 & 5 & 6 \\
\hline 1 & Employment contract & II.1 & 449 & 2.86 & 1.11 \\
\hline 2 & Employment security & II.2 & 449 & 3.07 & 0.96 \\
\hline 3 & A sense of stability and safety at work & II.3 & 449 & 3.03 & 1.00 \\
\hline 4 & Certainty that wages will be paid on time & II.4 & 449 & 3.19 & 0.95 \\
\hline 5 & A sense of fair pay & II.5 & 449 & 2.95 & 1.08 \\
\hline 6 & Equal treatment of all workers & II.6 & 449 & 2.92 & 1.02 \\
\hline 7 & Good open communication & II.7 & 449 & 2.98 & 1.00 \\
\hline 8 & Good relations with colleagues & II.8 & 449 & 3.02 & 1.02 \\
\hline 9 & Correct relations with the management & II.9 & 449 & 2.93 & 1.06 \\
\hline $10^{*}$ & Praise from the superior & II.10 & 449 & 2.73 & 1.14 \\
\hline $11^{*}$ & Consultation of supervisors with the staff on & & & & \\
\hline & the future of the company & II.11 & 449 & 2.65 & 1.11 \\
\hline 12 & Importance of the tasks to be carried out & II.12 & 449 & 2.73 & 1.03 \\
\hline 13 & Drawing satisfaction from your job & II.13 & 449 & 2.94 & 1.04 \\
\hline $14 *$ & Opinions about the company I work for & II.14 & 449 & 2.69 & 1.12 \\
\hline 15 & Fixed working hours & II.15 & 449 & 2.84 & 1.17 \\
\hline 16 & Flexible working hours & II.16 & 449 & 2.45 & 1.26 \\
\hline 17 & Observance of labour law principles & II.17 & 449 & 2.92 & 0.97 \\
\hline 18 & Absence of mobbing and discrimination & II.18 & 449 & 3.14 & 1.00 \\
\hline 19 & Stress-free work & II.19 & 449 & 3.02 & 1.00 \\
\hline $20^{*}$ & Possibility of promotion & II.20 & 449 & 2.90 & 1.14 \\
\hline $21 *$ & Opportunity for professional development & II.21 & 449 & 2.95 & 1.05 \\
\hline 22 & Integration meetings/visits & II.24 & 449 & 2.61 & 1.27 \\
\hline 23 & Fear of punishment & II.34 & 449 & 2.12 & 1.29 \\
\hline 24 & Fear of dismissal & 449 & 2.07 & 1.33 \\
\hline & & & & \\
\hline
\end{tabular}

*The table indicates the motivation factors that are the subject of the analysis in Chapter 4.

Source: own elaboration based on empirical research results. 
while $14.9 \%$ are employees holding managerial positions. The respondents represented mainly the following industries: furniture production $-21.2 \%$, machinery and equipment production $-19.8 \%$, food production $-14.7 \%$, and metal production $-12.2 \%$ of respondents. In order to check the reliability of the questions concerning the motivation factors, the alpha-Cronbach reliability test was applied. The results indicated values in the range of 0.9 (for factors motivating to work) and 0.6 for material non-monetary factors motivating to work, therefore the questionnaire is characterized by a very high reliability of scale. Table 2 presents the results of average and standard deviations of intangible factors motivating to work in the scale of $0-4$.

Table 2 presents the structure of responses of the respondents in relation to non-material motivation factors. The analysis showed significant differences between the assessment of particular motivation factors. From the non-material factors of motivation of respondents included in the questionnaire, the most important ones are: certainty of receiving remuneration on time (II.4) - mean $3.19 \pm 0.95$ points, lack of mobbing and discrimination (II.18) - mean $3.14 \pm 1.00$ points and employment security (II.2) - mean $3.07 \pm 0.96$ points. The least effective factors include: fear of dismissal (II.34) - mean 2.07 \pm 1.33 points and fear of punishment (II.32) - mean $2.12 \pm 1.29$ points.

Figure 3 presents the results of empirical research on intangible factors motivating to work.

Table 3 presents the detailed results of average and standard deviations of material non-monetary factors motivating to work on the scale of 0-4.

The analysis of the empirical research showed that for the respondents the most motivating of the listed financial factors were: participation in training (II.23) - mean $2.67 \pm 1.17$ points and holiday vouchers (II.29) - mean $2.65 \pm 1.26$ points. The

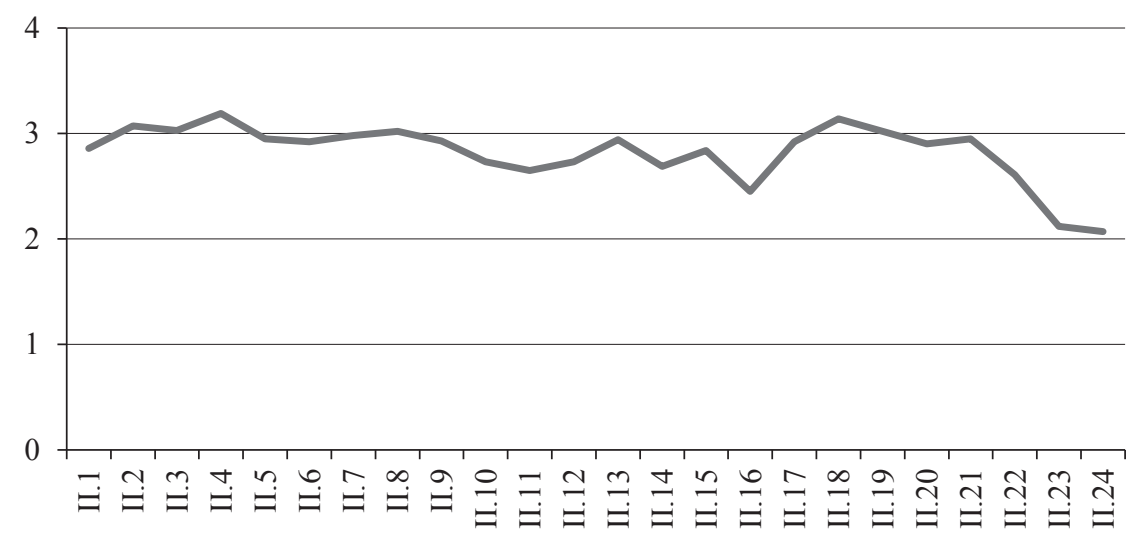

Fig. 3. Intangible incentives to work

Source: own elaboration based on empirical research results. 
Table 3. Averages and standard deviations of material non-monetary factors motivating to work

\begin{tabular}{|l|l|c|c|c|c|}
\hline No. & \multicolumn{1}{|c|}{$\begin{array}{c}\text { Factors motivating material } \\
\text { non-monetary work }\end{array}$} & $\begin{array}{c}\text { Factor } \\
\text { no. }\end{array}$ & $\mathrm{n}$ & Medium & $\begin{array}{c}\text { Standard } \\
\text { deviation }\end{array}$ \\
\hline 1 & Subsidy for studying & II.22 & 449 & 2,60 & 1.24 \\
\hline $2 *$ & Participation in training courses & II.23 & 449 & 2.67 & 1.17 \\
\hline 3 & Discount on purchase of company's goods & II.27 & 449 & 2.53 & 1.25 \\
\hline 4 & Christmas vouchers & II.29 & 449 & 2.65 & 1.26 \\
\hline 5 & Subsidies to the cinema gym, swimming pool, etc. & II.30 & 449 & 2.49 & 1.32 \\
\hline 6 & Use of a company car, laptop and phone & II.31 & 449 & 2.36 & 1.30 \\
\hline
\end{tabular}

*The table indicates the motivation factors that are the subject of the analysis in Chapter 4

Source: own elaboration based on empirical research results.

respondents were least motivated by the following factor: use of company car, laptop and phone (II.31) - mean score of $2.36 \pm 1.30$ points. Figure 4 presents the results of research on material non-monetary motivating factors.

Table 4 presents the mean and standard deviations of material monetary factors motivating to work on the scale of $0-4$.

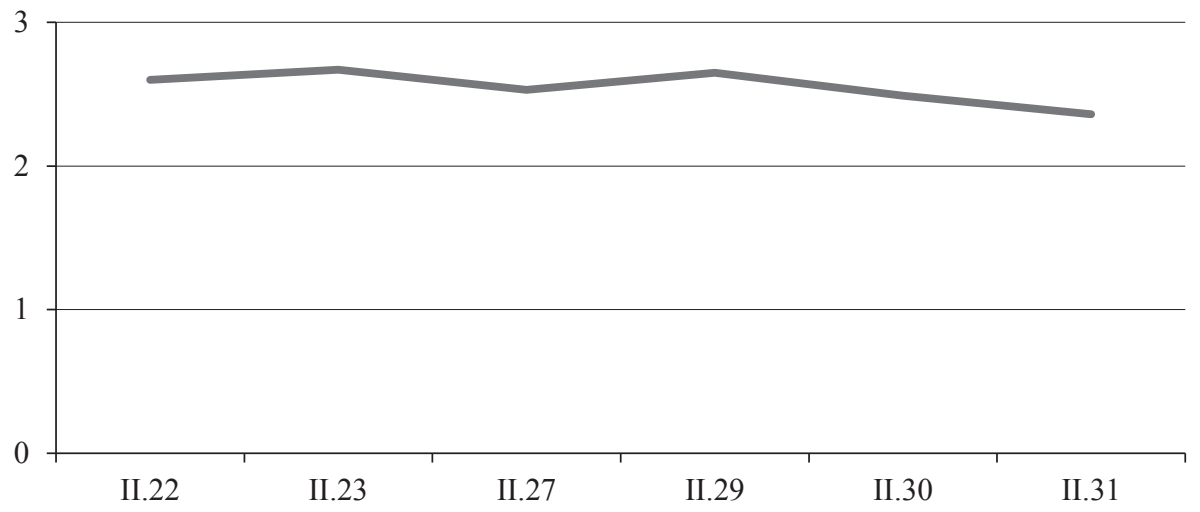

Fig. 4. Material non-monetary factors motivating to work

Source: own elaboration based on empirical research results.

Table 4. Averages and standard deviations of material monetary factors motivating to work

\begin{tabular}{|c|l|c|c|c|c|}
\hline No. & \multicolumn{1}{|c|}{$\begin{array}{c}\text { Incentive factors to work - } \\
\text { tangible cash }\end{array}$} & Factor no. & $\mathrm{n}$ & Medium & $\begin{array}{c}\text { Standard } \\
\text { deviation }\end{array}$ \\
\hline 1 & Increase in salary & II.25 & 449 & 2.99 & 1.10 \\
\hline 2 & Receiving cash prizes & II.26 & 449 & 2.96 & 1.16 \\
\hline 3 & Share in company profits & II.28 & 449 & 2.70 & 1.25 \\
\hline 4 & Fear of losing a bonus & II.33 & 449 & 2.13 & 1.29 \\
\hline
\end{tabular}

Source: own elaboration based on empirical research results. 


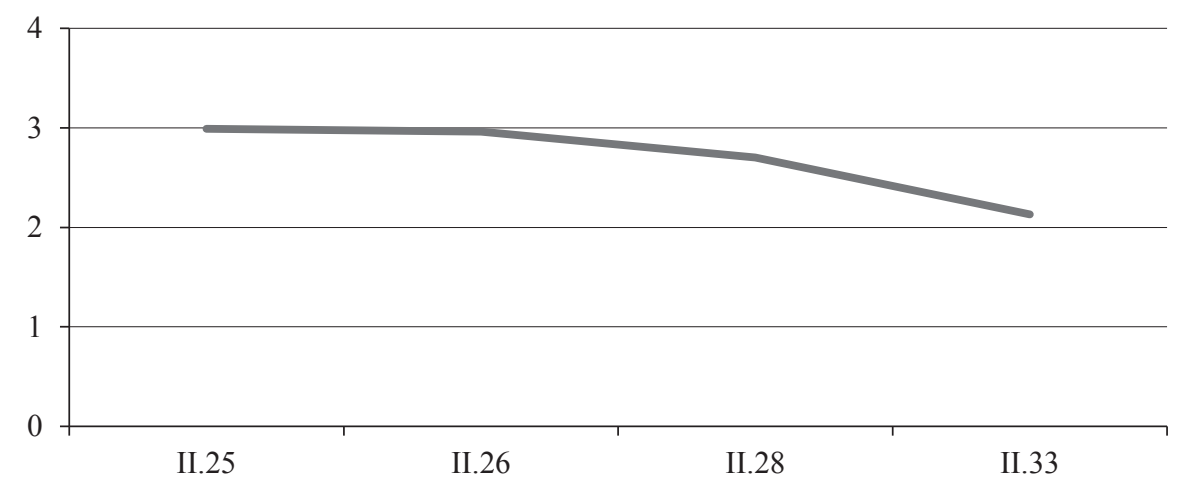

Fig. 5. Material monetary factors motivating to work

Source: own elaboration based on empirical research results.

The structure of the respondents' responses to the assessment of material effectiveness of monetary motivating factors presented in Table 4 indicates that the most motivating factors for the respondents are: salary increase (II.25) - mean $2.99 \pm 1.10$ points and receiving monetary awards (II.26) - mean $2.96 \pm 1.16$ points. The respondents were least motivated by the following factor: fear of losing a bonus (II.33) - mean $2.13 \pm 1.29$ pts. Figure 5 presents material monetary factors motivating to work.

\section{The use of information and communication technologies as an element in the development of incentive schemes}

Information and communication technologies today can be successfully used in the implementation of incentive schemes. Among non-material and material non-monetary ICT motivating factors can be used, among others, in the processes of shaping good open communication, in conveying praise from a superior, during consultations between superiors and the staff concerning the future of the company, opinions about the company and opportunities for promotion and professional development. Table 5 presents the possibilities of using information and communication technologies in the implementation of the assumptions of the incentives system using the example of selected motivation factors. The selection was made on the basis of observations of the working environment in enterprises selected for research and by means of literature analysis.

Good and open internal communication is very important in the process of building a motivated staff. For this purpose, companies more and more often use the Intranet - a platform facilitating communication between the donor and employees and the company's employees themselves. Intranet is a local network which is accessible to the company's employees from the level of an Internet browser, without 
Table 5. Use of information and communication tools in motivating employees

\begin{tabular}{|c|l|l|}
\hline No. & \multicolumn{1}{|c|}{ Motivation factors } & \multicolumn{1}{c|}{ Using } \\
\hline 1 & Good open communication & Intranet, Web 2.0 \\
\hline 2 & Praise from the superior & Intranet, Web 2.0 \\
\hline 3 & $\begin{array}{l}\text { Consultation of supervisors with the } \\
\text { staff on the future of the company }\end{array}$ & Intranet, Web 2.0 \\
\hline 4 & Opinions about the company I work for & Intranet, electronic mail \\
\hline 5 & Possibility of promotion & E-learning, educational platforms, gamification \\
\hline 6 & $\begin{array}{l}\text { Opportunity for professional } \\
\text { development }\end{array}$ & E-learning, educational platforms, gamification \\
\hline 7 & Participation in training courses & E-learning, educational platforms, gamification \\
\hline
\end{tabular}

Source: own elaboration based on empirical research results.

the need to access the Internet. Thanks to this modern solution, it is possible to exchange and manage information, documentation, multimedia files or internal regulations and procedures applied in the company. This solution also gives the possibility to integrate new employees by providing information related to the principles of the company's operation and the control of tasks entrusted to employees and teams. Another possibility of using the Intranet is to provide praise and consultation by superiors with the staff concerning the future of the company. The Intranet gives the possibility of transmitting information about the employer, the company in which they work and information about the business situation of the company and its goals and plans for the future. This form of communication also gives the opportunity to communicate one's opinions, suggestions and ideas concerning the company's activity without fear of transferring this information to the group's formula [Sala 2019].

The development of Web 2.0 instruments enables everyone, without the need to acquire additional knowledge and knowledge of the rules of hypertext, to create and publish information online and to communicate live and exchange content. Users can shape virtual reality, and internet websites are often anonymous and not static, but dynamic, enriched with interactive elements created with the use of information and communication tools [Sidorczuk, Gogiel 2012, pp. 2-3].

E-learning is another example of the use of ICT in the process of implementation of incentive systems. It is a form of distance learning with the use of interactive computer techniques, a method of gaining knowledge with the use of electronic media in isolation from educational institutions, trainers, teachers, and educational programmes, for the purpose of improving qualifications. Nowadays, both management and employees are aware of the need for education, the measurable results of which will always be the basis for competitive advantage for the donor. The development of remote learning depends mainly on the development of information and communication technologies - it is now becoming a natural thing to 
include these programmes in the employee motivation system. ICT facilitates knowledge transfer and is an effective solution in terms of flexibility and quality of teaching [Kozioł 2013, pp. 45-50]. Facilitating the implementation of the "lifelong learning" function is not without significance here. The Lifelong Learning (LLL) concept assumes that every participant, after entering the labour market, should continuously improve his or her basic competences in order to be ready for career change at any time, even at the end of his or her working life [Perspektywa uczenia się... 2013].

In the era of the cult of continuous improvement of qualifications and development, educational platforms play a key motivational role, and users of educational platforms use the available knowledge and create new knowledge [Plebańska, Kopciał 2013, p. 42].

Gamification is another example of the use of ICT in motivation systems. According to Zinger's definition, "gamification is the use of game thinking and game mechanisms to work" [Zinger 2014, p. 32]. It is "the use of game-design techniques in non-game contexts to engage people and solve problems" [De-Marcos et al. 2014, p. 82]. In practice, gamification is used in the area of employee training as an innovative training tool for educational purposes. Playing games can give authority to control the behaviour of employees, first of all by rewarding proper behaviour. As research shows, the use of such methods may result in intensification of desirable employee behaviour [Woźniak 2015, pp. 20-21; Misztal 2015, pp. 91-96].

\section{Conclusion}

Information and communication technologies have penetrated all areas of human resource management. They are more and more often used for competence management and broadly understood control. There is a noticeable trend, in which companies strive to improve efficiency and productivity, optimize the resources used with the participation of information and communication technology. The dynamics of changes taking place in the economy and society prompts to make comprehensive use of information and communication technologies, also in areas traditionally considered as "soft" HR. The economic reality is changing rapidly, among other things, under the influence of demographic and cultural changes or reorganization, and ss a result, both the environment and the internal situation of enterprises are changing dynamically. Energetic, creative and enthusiastic employees are the main source of company value creation, and therefore decide about the competitive advantage of the organization to a greater extent than technological or financial resources. For years, scientists and practitioners have been reflecting on the sources of human activity and involvement, which can be seen from analysing the tools of employee empowerment. 


\section{References}

Baun Ch., Kunze M., Nimis J., Tai S., 2011, Cloud Computing. Web-Basierte Dynamische IT-System, Springer Verlag, Berlin Heidelberg.

Capron, H., 2000, Computers for an information Age, Prentice Hall.

Chomiak-Orsa I., 2013, Zarzadzanie kapitałem relacyjnym w procesie wirtualizacji organizacji. Podejście modelowe, Wydawnictwo Uniwersytetu Ekonomicznego we Wrocławiu, Wrocław.

Chomiak-Orsa I., Kołtonowska A., 2016, Metody i narzędzia rozwiazywania problemów komunikacji $w$ relacji It-biznes $w$ projektach informatycznych, Informatyka Ekonomiczna Business Informatics, 3(41).

Chomiak-Orsa I., Dziembek D., Jelonek D., Nowicki A., Rot A., Sitarska M., Stępniak C., Turek T., Zygała R., 2010, [in:] A. Nowicki, T. Turek (eds.), Technologie informacyjne dla ekonomistów. Narzędzia. Zastosowania, Wydawnictwo Uniwersytetu Ekonomicznego we Wrocławiu, Wrocław.

Crozier M. 1993, Przedsiębiorstwo na podstuchu: jak uczyć się zarzqdzania postindustrialnego, PWE, Warszawa.

De-Marcos L., Dominguez A., Saenz-de-Navarrete J., Pages C., 2014, An empirical study comparing gamification and social networking on e-learning, Computers Education, 75.

Gabryelewicz I., Krupa P., Sadłowska-Wrzesińska J., 2017, Online measurement of work safety culture - statement of research, MATEC Web of Conferences 94, https://www.matec-conferences.org/ articles/matecconf/pdf/2017/08/matecconf_cosme2017_06008.pdf

https://proedukator.wordpress.com/2012/01/04technologie-informacyjno-komunikacyjne-pojęcie ogólne/ (access 26.11.2019)

Juchnowicz M., 2014, Zarzqdzanie kapitałem ludzkim. Procesy - narzędzia-aplikacje, PWE, Warszawa.

Klonowski Z., 2004, Systemy informatyczne zarzqdzania przedsiębiorstwem. Modele rozwoju i wtaściwości funkcjonalne, Oficyna Wydawnicza Politechniki Wrocławskiej, Wrocław.

Kozioł M., 2002, Motywacja w pracy, Wydawnictwo PWN, Warszawa.

Kozioł M., 2013, Wykorzystanie e-learningu w procesie szkolenia pracowników małych i średnich przedsiębiorstw, Zeszyty Naukowe Wyższej Szkoły Ekonomicznej w Tarnowie, 22(1).

Kozioł L., Piechnik-Kurdziel A., Kopeć J., 2000, Zarzqdzanie zasobami ludzkimi w firmie - teoria i praktyka, Wyd. Biblioteczka Pracownicza, Warszawa.

Koźmiński A.K., Piotrowski W., 2010, Zarzqdzanie teoria i praktyka, Wyd. Naukowe PWN, Warszawa.

Krawczyk-Sokołowska, I., Mesjasz-Lech, A., Nowicka-Skowron, M., 2017, Rynek pracy a systemy wczesnego ostrzegania w zarzqdzaniu zasobami ludzkimi, [in:] K. Jędralska, W. Dyduch (eds.), Nauki o zarzqdzaniu. Dokonania, trendy, wyzwania, Wyd. UE w Katowicach, Katowice.

Leoński W., 2014, Technologie informacyjno-komunikacyjne jako czynnik poprawy konkurencyjności polskich przedsiębiorstw, Studia i Prace Wydziału Nauk Ekonomicznych i Zarządzania, 38(1).

Listwan T. (ed.), 2010, Zarzqdzanie kadrami, Wyd. C.H. Beck, Warszawa.

Marcelle G., 2000, Gender, Justice and ICTs, http://www.un.org/womenwatch daw/csw/marcello.ht.m (access 20.11.2019).

Misztal A., 2015, Grywalizacja w zarzadzaniu zasobami ludzkimi w przedsiębiorstwie, Nauki o Zarządzaniu Management Sciences, 3(24).

Nieckarz Z., 2011, Psychologia motywacji w organizacji, Difin, Warszawa.

Perspektywy rozwoju branzy ICT do roku 2025, 2017, https://www.parp.gov.pl/component/publications/publication/perspektywy-rozwoju-branzy-ict-do-roku-2025 (access 10.11.2019).

Perspektywa uczenia się przez całe życie, 2013, Załącznik do uchwały nr 160/2013 Rady Ministrów z dnia 10 września 2013 r., Międzyresortowy Zespół ds. uczenia się przez całe życie, Ministerstwo Edukacji Narodowej, Warszawa, www.men.gov.pl/images/mlodziez_zagranica/PLLL_2013_ 09_10zał_do_uchwały_RM.pdf (access 21.11.2019). 
Plebańska M., Kopciał P., 2013, Platforma e-learningowa jako narzędzie zarzqdzania wiedza, E-mentor, 2(49).

Proedukator, 2012, http://proedukator.wordpress.com/2012/01/04/technologieinformacyjnokomunika cyjne-pojecie-ogolne (access 17.11.2019).

Raport Tech Trends, 2017, The kinetic enterprise.

Sadłowska-Wrzesińska J., Nejman Ż., 2016, Organizacja bezpiecznej pracy jako pozapłacowy czynnik motywacji pracowniczej, Przedsiębiorczość i Zarządzanie, 17, 6(2).

Sala A., 2019, Wykorzystanie nowoczesnego intranetu $w$ organizacji, https://kadry.infor.pl/kadry/ $\mathrm{hrm} /$ komunikacja/538386,3, Wykorzystanie-nowoczesnego-intranetu-w-organizacji.html (access 26.11.2019).

Sambamurthy V., 2000, Business Strategy in Hypercompetitive Environment, Rethinking the Logic of IT Differentiation, [in:] R.W. Zmud (ed.), Framing the Domains of IT Management Projecting the Future through the Past, Pinnaflex, Cincinnati.

Schermerhorn J., 2008, Zarzqdzanie, kluczowe koncepcje, Polskie Wyd. Ekonomiczne, Warszawa.

Sępek M., 2010, System motywowania pracowników, Przedsiębiorczość i Zarządzanie, 6(11).

Sidorczuk A., Gogiel-Kuźmicka A., 2012, Biuletyn EBIB, 2(129), 1-15, 7.

Sobińska M., 2014, Innowacyjne modele biznesu dla IT - wyzwania i perspektywy rozwoju, Informatyka Ekonomiczna. Business Informatics, 1(31).

Sobińska M., 2016, Rola IT we wspótczesnych modelach biznesu, Informatyka Ekonomiczna. Business Informatics, 3(41).

Steczkowski J., 1995, Metoda reprezentacyjna w badaniach zjawisk ekonomiczno-społecznych, PWN, Warszawa-Kraków.

Stevenson D., 1997, The Independent ICT in Schools Commission, Information and Communications Technology in UK Schools. An Independent Inquiry, Independent ICT in Schools Commission, London.

Woźniak J., 2015, Grywalizacja w zarzq̨dzaniu ludźmi, Zarządzanie Zasobami Ludzkimi, 2(103).

Zinger D., 2014, Game on, A Primer on Gamification for Managers, T+D, V. 